DIGITALCOMMONS @WAYNESTATE -
Michigan Journal of Counseling:

Research, Theory and Practice

Volume 36 | Issue 2

Article 2

9-1-2009

\title{
An Investigation of School Counselor and School Counselor Trainee Activities
}

\author{
Aaron Oberman \\ The Citadel, aaron.oberman@citadel.edu \\ Jeannine Studer \\ The University of Tennessee, Knoxville \\ Donna Eby-Meeks \\ Devon Forest Elementary
}

Follow this and additional works at: https://digitalcommons.wayne.edu/mijoc

\section{Recommended Citation}

Oberman, A., Studer, J., \& Eby-Meeks, D. (2009). An Investigation of School Counselor and School Counselor Trainee Activities, Michigan Journal of Counseling, 36(2), 1-7. doi:10.22237/mijoc/1251763260

This Article is brought to you for free and open access by the Open Access Journals at DigitalCommons@WayneState. It has been accepted for inclusion in Michigan Journal of Counseling: Research, Theory and Practice by an authorized editor of DigitalCommons@WayneState. 


\section{An Investigation of School Counselor}

\section{and School Counselor}

\section{Trainee Activities}

\author{
Aaron Oberman, Ph.D. \\ The Citadel
}

Jeannine Studer, Ed. D.

The University of Tennessee, Knoxville

Donna Eby-Meeks, M.Ed.

Devon Forest Elementary

\section{Author Note}

Contact Aaron Oberman, Ph.D.

Assistant Professor of Counselor Education The Citadel

aaron.oberman@citadel.edu,843-953-7123

The ASCA National Model ${ }^{\circledR}$ School CounselorPerformance Standards were used to compare the types of activities conducted by professional school counselors and their perceptions of the activities conducted by their supervisees. School counselors who supervised trainees were asked to rate the frequency in which they conducted activities within these performance standards and the frequency in which they perceived their trainees conducted these same tasks. The researchers found a significant difference in all areas $(p<.05)$ of the compared activities.

Key Words: supervision, school counselor, ASCA Model, trainee activities he leaders of the American School Counselor Association (ASCA), the professional organization that creates policy and advocates for school counselors, state:

"[p]rofessional school counselors design and deliver comprehensive school counseling programs that promote student achievement. These programs are comprehensive in scope, preventative in design and developmental in nature (. ..) . The ASCA National Model $®$ brings professional school counselors together with one vision and one voice, which creates unity and focus toward improving student achievement" (ASCA, 2005 व 1).

The advantages of developmental, comprehensive school counseling programs (CDSC) have been espoused for decades (Gysbers, 2004), yet these programs were slow to emerge. In 1997, the ASCA Standards were developed to identify and monitor student competencies with a focus on student growth in the academic, career, and personal/social domains (ASCA, 2003). In 2001, the governing council of the American School Counseling Association took these Standards to the next level through the development of a template for professional school counselors to use in designing their own CDSC program. The result is the ASCA National Model ${ }^{\circledR}$ (ASCA).

Despite the ASCA's active campaign to promote awareness of the benefits of a CDSC program, many professional school counselors have not yet instituted a comprehensive, developmental school counseling program in their schools. In one study (Oberman \& Studer, $2008), 51 \%$ of the surveyed school counselors reported that they had not instituted a CDSC program in their schools, $26 \%$ of the participants reported having a comprehensive, developmental counseling program in place, and 23\% reported that they were in the process of implementing this type of program. School counselor training is disjointed when trainees are supervised by professional school counselors who work in a program that reflects a traditional, reactive school counseling program, but receive training in a CDSC perspective from their school counselor education program. As one high school counselor stated to a class of school counseling students who were learning about the benefits of a CDSC program, "you can forget everything you are learning in your classes since you will never use any of it when you enter the schools." It was clear from this statement that there was a disconnect between the phi- 
losophy of this practicing school counselor and those of the training program goals.

\section{School Counselor Performance Standards and CDSC Programs}

When the ASCA National Standards were first developed, there was some uncertainty as to whether the Standards were written for school counselor practitioners or for K-12 students. This confusion was clarified in the ASCA National Model: A Framework for School Counseling Programs in which it was stated that these competencies were designed "for students, not programs" (ASCA, 2003, p. 10). However, because school counselors serve as leaders of their program and are responsible for monitoring and assessing the effectiveness of their services, school counselor performance standards are also addressed in this document. Consequently, these standards were formatted into an evaluation document entitled School Counseling Standards: School Counselor Competencies that " . . . is organized and consistent with the ASCA National Model $\mathbb{R}$. . . . [and] will equip the school counselor with the skills to establish, maintain and enhance the developmental school counseling program in all three domains (academic, personal/social, and career" (ASCA, n.d. ๆ 6). Although graduates from school counseling programs are expected to fulfill the same roles and effectively perform the same competencies as their more experienced colleagues, the reality is that many competencies are not mastered until years of experience are attained.

\section{The Trainee in a CDSC Program}

Several researchers investigated school counseling programs that relate to the ASCA National Model ${ }^{\circledR}$. Schwallie-Giddis, ter Maat, and Pak (2003) asked school counselor trainees enrolled in their practicum to critique aspects of the Model, how the Model could be implemented in their practicum, and to share their suggestions with their site supervisors. The results of this study revealed positive feelings regarding the use of the Model not only for trainees but also for professional school counselor supervisors.

A study by Studer and Oberman (2006) was conducted to understand the types of trainee activities integral to the ASCA National Model ${ }^{\circledR}$ during their clinical experiences. In this research investigation, activities of trainees who were supervised in traditional programs were compared to the activities of school counselor students trained in a CDSC program. The results revealed that, regardless of the program structure in which they were placed for supervision, trainees received similar experiences in engaging in activities related to the various components of the ASCA Model ${ }^{\circledR}$.

The Council for the Accreditation of Counseling and Related Educational Programs (CACREP) standards also provide direction on the types of activities trainees are to obtain (e.g. direct activities such as group and individual counseling and indirect activities such as record-keeping and assessment instruments). Yet, there is little known about the types of opportunities provided to school counselor trainees that assist in their understanding of the school counselor's role within a CDSC program. Furthermore, there is little research on the types of activities that are conducted by professional school counselors in relationship to those conducted by their supervisees. When school counseling students graduate and matriculate into a school counselor role, they are often considered as fully functioning members of the profession and regarded as having the same skills as more experienced practitioners. This is an unfortunate expectation since school administrators may expect novice school counselors to engage in the same tasks as more experienced colleagues without benefit of the same experiences. To investigate these concerns, the researchers addressed the following research questions:

1. How do school counselor supervisors perceive the types of school counseling duties performed by school counselor trainees during their clinical experiences that are reflected in the ASCANational Model $\mathbb{R}$ School Counselor Performance Standards?

2. What duties do practicing professional school counselors perform that are reflected in the ASCANational Model $(\mathbb{R})$ School Counselor Performance Standards?

3. Are the duties performed by the professional school counselor similar to the perceived duties conducted by the trainee?

\section{Method}

\section{Participants}

The participants for this study included a national sample of professional school counselors who were members of the ASCA. From a list of 2,000 ASCA members, using simple random sampling, 500 professional school counselors were selected (every fourth name on the list) to participate, and were mailed a copy of the School Counselor Supervisor \& Trainee Michigan Journal of Counseling • 36:2 • Fall-Winter 2009 
Survey. A self-addressed, stamped envelope was provided to increase the return rate of the participants, and approximately three weeks later, a follow-up postcard was sent to all of the participants as a reminder to complete and return the survey.

\section{Instrument}

The researchers developed the instrument with items taken directly from the School Counselor Performance Standards developed by the American School Counselor Association (ASCA, 2003). Practicing professional school counselors served as a pilot group to review the instrument and to assess for content validity. After carefully considering their recommendations, minor revisions were made to the instrument. The School Counselor Supervisor \& Trainee Survey consisted of 25 questions divided into two sections: demographics, and school counselor performance standards. The demographics section contained seven questions and included questions on gender, years of experience as a school counselor, year of graduation from the participant's school counseling program, the philosophical orientation of that training program (e.g. taught from a CDSC program), type and amount of supervision training received, if he/she described their program as one that met the criteria for a CDSC program, and the number of years supervising school counselor trainees. The second section consisted of 18 questions related to the School Counselor Performance Standards identified in the ASCA National Model ${ }^{\circledR}$ (ASCA). Participants were asked to indicate how often they performed each activity, and the extent to which their trainee(s) usually performed each activity based on a four-point scale: 1 (never), 2 (rarely), 3 (sometimes), and 4 (frequently). These activities included tasks based on: planning and implementing the guidance curriculum; engaging in individual planning; providing individual counseling; leading group counseling; engaging in consultation; making appropriate referrals; providing a comprehensive/developmental program; engaging in management system activities; engaging in program planning; working with an advisory board; collecting and analyzing data; monitoring student academic growth; developing an activity calendar; evaluating the program; being a student advocate, and; evaluating student improvement. The researchers analyzed the data using SPSS to compare means and compute independent sample t-tests. An initial alpha level of $p<.05$ was used for all data sets. After correcting for Type I error using Bonferroni's method, the criteria for significance was adjusted to $\mathrm{p}<.003$.

\section{Results}

A total of 45 school counselors completed and returned the instrument. Females comprised $84 \%$ of the participants, and the average length of time that participants worked as a school counselor was 12 years. The modal year of graduation from a school counseling program was 1993, with a wide range of graduation dates that included the years from 1969 to 2005 . In addition, 71\% reported being trained from a comprehensive, developmental framework. Thirty-three percent of the participants reported not having any training in supervision, while $67 \%$ reported receiving at least one type of training that varied from coursework to workshops, and/or conference presentations. Approximately 58\% of the participants indicated that they were providing leadership from a CDSC perspective, less than $1 \%$ indicated that their program did not reflect the philosophy of a CDSC program, and 33\% indicated that their program was in transition from one that reflected traditional programming to one of a comprehensive, developmental approach. These numbers do not equal 100\% because several participants did not respond to this question.

\section{Research Question 1}

The five most common activities that the supervisor reported were conducted by the school counselor trainee included: leading individual counseling $(\mathrm{M}=3.09$, $\mathrm{SD}=1.15)$, monitoring student/client progress $(\mathrm{M}=$ $2.91, \mathrm{SD}=1.20)$, leading small group counseling $(\mathrm{M}=$ $2.82, \mathrm{SD}=1.17)$, providing services within the overall comprehensive school counseling program $(\mathrm{M}=2.76$, $\mathrm{SD}=1.23)$, and consulting $(\mathrm{M}=2.71, \mathrm{SD}=1.22)$. See Table 1 .

\section{Research Question 2}

The five most common duties performed by the professional school counselor included: providing consultation $(\mathrm{M}=3.84, \mathrm{SD}=.37)$, leading individual counseling $(\mathrm{M}=3.76, \mathrm{SD}=.49)$, monitoring student/client progress $(\mathrm{M}=3.71, \mathrm{SD}=.51)$, making appropriate referrals $(\mathrm{M}=3.71, \mathrm{SD}=.51)$, and serving as an advocate for all students $(\mathrm{M}=3.67, \mathrm{SD}=.57)$. See Table 1 .

\section{Research Question 3}

While many of the duties performed by the school counseling supervisor are perceived as being similar to those of the school counseling trainee, there was a significant difference (see Table 1) between the amount of time the supervisor spent on these activities compared to how often the supervisor perceived that the trainee conducted the activities. The duties with the greatest disparity between supervisor and trainee included mak- 
ing appropriate referrals, discussing program planning strategies with the administration, providing program management systems, monitoring student academic growth, consulting with parents and teachers, and analyzing the school counseling program. An adjusted alpha of $p<.001$ was used to account for Bonferroni's correction. All of the variables, with the exception of the amount of time spent conducting small group counseling, $(\mathrm{p}<.025)$ were significantly different when comparing the supervisor and the supervisor's perception of the counselor-in-training.

\section{Discussion}

From the results of this study, it appears that both practitioners and trainees have opportunities to engage in activities that are supported within a CDSC program. Yet in all areas the supervisor reported that the trainee performed these essential tasks less frequently. For example, supervisors reported that they monitored student academic growth "sometimes to frequently" $(\mathrm{M}=$ 3.60); however, when asked how often their trainee(s) conducted this activity the respondents indicated "rarely to sometimes" $(\mathrm{M}=2.53)$.

One reason these differences may exist are the types of requirements mandated by accrediting bodies such as the CACREP and state departments. For example, during the clinical experience of practicum, CACREP requires a minimum of 100 contact hours including a minimum of 40 direct hours with students, such as conducting individual and group counseling. In the clinical experience of internship, a minimum of 600 contact hours is required including a minimum of 240 direct hours (CACREP, 2009). Although obtaining these direct hours is essential to training, it is possible that trainees are unable to engage in the same tasks performed by their supervisor for several reasons: a) time spent on mandated requirements specified by the training program and/or the school site; b) the type of activity that may require specific, special training that the trainee has not acquired, and; c) the nature of the activity may require specific accountability standards (e.g. scholarship recommendations) that supervisors need to complete due to knowledge of the situation and/or student's background.

Consultation was one area performed frequently by both the trainee and supervisor. Consultation with others can impact change at many levels, and when the school counselor is able to view the problem from various perspectives, affirmative change may provide teachers and parents with a source of support and empowerment (Clemens, 2007). Practicing school counselors identified this as an activity that they performed on a "frequent" basis $(\mathrm{M}=3.84)$. In contrast, participants stated that their trainees perform this task "rarely" to "sometimes," $(\mathrm{M}=2.71)$. The frequency differences in conducting this activity could be due to the inexperience of the trainee, discomfort with this process due to their novice status, or a lack of opportunity. Although CACREP specifies knowledge in consultation as a training component, and school counselor educators are required to teach consultation skills in their program, quantity and quality spent in this area differ among programs (Davis, 2003).

Monitoring student progress was also a variable ranked as a top activity performed by both supervisors and trainees. Yet, the types of activities performed within this item may vary between supervisors and trainees. For instance, practicing school counselors/supervisors, especially those at the high school level, may focus on evaluating earned credits and/or grades in designated classes for the purposes of promotion, matriculation, or college scholarships. Conversely, trainees performing responsibilities in this area may be engaged in different but equally important responsibilities such as assisting students in recognizing barriers to academic success, setting goals, or identifying students who need intervention. Obtaining more detailed information on the specific tasks within each of these school counselor competencies is needed to fully understand how specific tasks may be different or similar between novice and experienced school counseling professionals.

At the other end of the spectrum, collecting and analyzing data were among the least frequently conducted activities by counselors and trainees. Educational programs require accountability procedures such as data collection and documentation to show effectiveness, and the overall success of a school counseling program and counselor interventions need to be quantified (Schwallie-Giddis, et al., 2003). Data Collection is an essential component advocated by the ASCA who "calls out to all school counselors to use data to drive important decisions and to evaluate those decisions . .. " (Sabella, 2006, p. 412). In response to concerns about data collection and analysis, the National School Counseling Resource Center (NSCRC) was developed to provide assistance with research initiatives, and to develop research protocols and instrumentation (Sabel- 
la). Finally, the School Counselor Performance Standards (ASCA, 2003) and School Counseling Standards: School Counselor Competencies (ASCA, n.d.) are excellent tools for tracking activities within a CDSC program, for identifying and evaluating school counselor performance from program admission and throughout the professional career of the school counselor.

\section{Limitations}

There are a number of limitations in this study. First, the low response rate was a concern. Although the researchers randomly selected participants from the ASCA member list, many of the counselors who received the survey may not have supervised a school counseling trainee due to being a new school counselor or due to their proximity (i.e. school of employment is not near a college or university with a school counseling program). This drawback to the current study will be modified in future studies on this topic. Second, the types of activities reported by the respondents may not be reflective of those of non-respondents. Third, the self-report nature of the study may reflect participants' desire to appear updated on current trends (e.g. providing leadership in a CDSC program) and respond in what is perceived as "professionally correct" rather than report their actual program format. Fourth, since all the participants were members of the ASCA, results are difficult to generalize. Future replications of this study could examine the responses of school counselors across the country that are members of the ASCA, with those who are not members of this professional organization. In addition, instrument items were taken directly from the ASCA National Model: A Framework for School Counseling Programs materials (ASCA, 2003) and tested for content validity, yet additional psychometric analyses are needed.

\section{Implications}

This study provides a view of the activities performed by the professional school counselor and those activities these supervisors perceived to be performed by their school counselor trainee under supervision. Counselor educators work in partnership with professional school counselors to provide quality experiences to school counselor trainees, yet if supervisees are not provided with comprehensive experiences in all facets of school counseling, training gaps exist. Even though school counselors may not yet identify their program as one that mirrors the philosophy of the ASCA National Model ${ }^{\circledR}$, many of the tasks performed by practicing school counselors may be reflective of the philosophy behind the model. Therefore, if the trainee is placed in a traditional program structure, the trainee can identify tasks that reflect those suggested by a CDSC program to give him/her an opportunity to perform these tasks. A better understanding of the activities that assist in transforming a traditional school counselor program into one that reflects the current trends in school counseling programming can then be part of the practicum or internship contract that outlines performance expectations.

\section{Conclusion}

More recently, the ASCA has placed a greater focus on expanding the original counselor performance standards that first appeared in the ASCA National Model: A Framework for School Counseling Programs (ASCA, 2003) for the purposes of self-evaluation, forming a plan for professional growth, and serving as a guide for performance assessment. The School Counseling Standards: School Counselor Competencies (ASCA, n.d.) is a revised version of the original performance standards for assisting school counselors and their supervisors in monitoring time spent within each of the model components. This document can also be used to identify various tasks for trainees to use in their clinical experiences contract, and to gain experiences aligned to those within a CDSC program. Recently, the Southern Association of Counselor Educators and Supervisors (SACES) provided an opportunity for interested individuals to discuss how these competencies could be used throughout professional development. An outcome of this discussion was to select specific evaluative items to monitor and assess pre-candidate school counseling students, and other items to serve as program or practitioner evaluative attributes as the school counselor professional gains experience (SACES, Jan 24,2008$)$. Supervisors are urged to assess their current activities and to collaborate with local training programs so that experiences provided to trainees mirror those that are advocated through the ASCA National Model ${ }^{\circledR}$. An end result could be a better understanding of the roles and tasks of the school counselor practitioner, the tasks trainees have mastered, and those areas in which experience is needed. 


\section{References}

American School Counselor Association (n.d.). School counseling performance standards. Alexandria, VA: Author.

American School Counselor Association (2003). The ASCA national model: A framework for school counseling programs. Alexandria, VA: Author.

American School Counselor Association (2005). Position statement: Comprehensive school counseling programs. Retrieved May 8, 2008, from http://www.schoolcounselor.org

Council for Accreditation of Counseling and Related Educational Programs (2001). 2009 standards. Retrieved June 16, 20098, from http://www.cacrep.org/2009standards.html

Clemens, A. (2007). Developmental counseling and therapy as a model for school counselor consultation with teachers. Professional School Counseling, 10, 352-359.

Davis, K. M. (2003). Teaching a course in school-based consultation. Counselor Education and Supervision, 42, 275-285.

Gysbers, N. C. (2004). Comprehensive guidance and counseling programs: The evolution of accountability. Professional School Counseling, 8, 1-14

Oberman, A. H., \& Studer, J.R. (2008). The professional school counselor and performance standards: how is time spent? Tennessee Counseling Association Journal, 2, 36-50.

Sabella, R. A. (2006). The ASCA national school counseling research center: A brief history and agenda. Professional School Counseling, 9, 412-415.

Schwallie-Giddis, P., ter Maat, M., \& Pak, M. (2003). Initiating leadership by introducing and implementing the ASCA national model. Professional School Counseling, 6, 170-173.

Southern Association for Counselor Educators and Supervisors (2008, Jan). In C. Stone (Chair). Meeting conducted through a conference call of counselor educators in SACES.

Studer, J. R., \& Oberman, A. H. (2006). The use of the ASCA national model® in supervision. Professional School Counseling, 10, 82-87.

Note: The Citadel Foundation provided funding for this research project. 


\section{Appendix}

\section{Table 1}

Comparison of Supervisor and Perceived Trainee Duties, and Rank of Activity Frequency

\begin{tabular}{|c|c|c|c|c|c|c|c|}
\hline \multirow[b]{2}{*}{ Variables } & \multicolumn{2}{|c|}{ Supervisor } & \multirow[t]{2}{*}{ Rank } & \multicolumn{2}{|c|}{ Trainee } & \multirow[t]{2}{*}{ Rank } & \multirow[b]{2}{*}{$p$} \\
\hline & M & $\mathrm{SD}$ & & M & SD & & \\
\hline Guidance Curriculum & 3.36 & .908 & 9 & 2.67 & 1.168 & 6 & .001 \\
\hline Individual Planning with Students & 3.40 & .751 & 8 & 2.64 & 1.246 & 8 & .000 \\
\hline Individual Planning with Parents & 3.11 & .959 & 14 & 2.18 & 1.051 & 12 & .000 \\
\hline Conduct Individual Counseling & 3.76 & .484 & 2 & 3.09 & 1.145 & 1 & .001 \\
\hline Conduct Small Group Counseling & 3.31 & .925 & 11 & 2.82 & 1.173 & 3 & .025 \\
\hline Consultation & 3.84 & .367 & 1 & 2.71 & 1.218 & 5 & .000 \\
\hline Referrals & 3.71 & .506 & 3 & 2.38 & 1.284 & 11 & .000 \\
\hline Comp/Developmental Program & 3.56 & .725 & 7 & 2.76 & 1.228 & 4 & .000 \\
\hline Management System & 3.24 & .830 & 13 & 2.02 & 1.118 & 15 & .000 \\
\hline Program Plan with Administration & 3.27 & .837 & 12 & 1.98 & 1.033 & 16 & .000 \\
\hline Meet with Advisory Council & 2.16 & 1.167 & 18 & 1.33 & .674 & 18 & .000 \\
\hline Collect Data & 2.91 & .996 & 16 & 2.16 & 1.147 & 13 & .000 \\
\hline Analyze Data & 3.04 & .999 & 15 & 2.13 & 1.198 & 14 & .000 \\
\hline Monitor Student Academics & 3.60 & .539 & 6 & 2.53 & 1.179 & 9 & .000 \\
\hline Develop Program Calendar & 3.33 & .953 & 10 & 2.49 & 1.236 & 10 & .000 \\
\hline Analyze Program & 2.82 & 1.007 & 17 & 1.80 & .991 & 17 & .000 \\
\hline Student Advocate & 3.67 & .564 & 5 & 2.67 & 1.297 & 6 & .000 \\
\hline Monitor Student Progress & 3.71 & .506 & 3 & 2.91 & 1.203 & 2 & .000 \\
\hline
\end{tabular}

Note. Table 1 compares the supervisor rating of how often he/she conducts the activities with his/her rating

of how often their supervisee(s) conducts the activities. In addition, the $p$-values are reported comparing the differences between how often the supervisee conducts the activities with how often he/she perceives their trainee to conduct the activities specified by ASCA National Model School Counselor Performance Standards at an alpha level of $p<.05$. 